\title{
Declaration regarding the escalating social and political situation in Moldova after the parliamentary elections of April 5, 2009
}

Expressing our concern regarding the worsening social and political situation after the 5 April 2009 parliamentary elections and, being worried that inadequate interpretations of these events serve as justification for decisions and actions that threaten to polarise Moldovan society further, we declare:

On 7 April 2009, spontaneous and peaceful demonstrations took place in the centre of Chişinău. This generally peaceful event was used to provoke violent and criminal acts resulting in the devastation of the Parliament and Presidential buildings. The law enforcement bodies through their actions were not capable to prevent the acts of violence and vandalism.

We categorically condemn such outrageous acts of violence and vandalism. However, we consider it inadmissible to present all protests through the prism of these criminal acts. In particular, it is utterly unjustified to shift responsibility from a small group of violent persons to a far larger gathering of peaceful protesters or to political leaders, some of whom, in fact, tried to stop the violence. The peaceful protests did not have an anti-state nature.

The acts of violence cannot be justified in any way and should be investigated by the competent authorities, but we believe that those peaceful protests were fuelled by doubts regarding the fairness of the elections and distrust in public institutions, including those that administrated the electoral process. Those events were largely triggered by the dissatisfaction of young people with the social and economic situation and the feeling of uncertainty about their future prospects in the Republic of Moldova.

The post-election statements made by the head of state have only contributed to inflaming such suspicions and provided an extra motivation for people to go on the streets.

These regrettable acts of violence and vandalism are now fully exploited by the authorities to intimidate the opposition and civil society and further restrict the already fragile fundamental rights and liberties of citizens. The authorities have further restricted access to public radio and TV, the internet and other media. The authorities have launched a massive brainwashing campaign to discredit the participants in the peaceful protests, the opposition and those having different opinions.

The head of state is making extremely grave accusations against some political leaders, describing their actions as a 'coup d'état', 'anti-constitutional plot', etc., even before any investigations or court rulings in this regard. Such statements tend to 
heighten the tensions further and polarise Moldovan society. By placing all the responsibility for the recent events on the political opposition and Romania, the authorities are creating an internal and external enemy which may be used to justify the government's failures.

We believe that preconditions are being created for the establishment of a police and dictatorial regime in the Republic of Moldova.

A reversal of the current disturbing trends is absolutely essential in order to avoid any further exacerbation of the political and economic crisis, prevent the international isolation of the country similar to that of Belarus and avoid compromising the European future of Moldova. It will be impossible for the country to get out of the crisis without the engagement of a broad spectrum of political actors and stakeholders, civil society and international organisations.

The authorities of Moldova have a special role to play in overcoming this crisis and therefore, we ask them to:

- refrain from any actions or declarations which could deteriorate the situation further

- give up any virulent messages as necessary to create an enabling environment for political dialogue to help overcome this conflict situation

- act strictly within the limits of the law in order to prevent any new acts of violence

- make public lists containing the names of arrested persons and provide these persons with access to lawyers and human rights organisations

- avoid any politically-motivated persecutions

- initiate a comprehensive and transparent investigation, with international participation, into the causes that led to the acts of vandalism; identify persons who have manoeuvred a part of the otherwise peaceful protesters towards the Presidency and the Parliament compound; identify persons who have instigated the acts of violence and crime; and review whether the actions of law enforcement troops were proportionate to the situation and in accordance with their mandate

- safeguard freedom of movement for citizens

- assure freedom of opinion and speech, and safeguard the inviolability of individual freedoms, personal safety and security

- actively contribute to the elimination of all suspicions related to the fairness and accuracy of the election results. 
We call on all media institutions, and particularly on the Public Broadcasting Company Tele-Radio Moldova, to cover correctly and impartially the political and social developments after the parliamentary elections of 5 April, with the equal and nondiscriminatory participation of all parties concerned.

\section{Chisinau, 9 April 2009}

Signed by:

Arcadie Barbăroşie, Director, Institute for Public Policies (IPP)

Igor Boțan, Director, Association for Participatory Democracy (ADEPT)

Viorel Cibotaru, Director, European Institute of Political Studies (IESPM)

Nadine Gogu, Interim Director, Centre of Independent Journalism (CIJ)

Vlad Lupan, independent expert

Ion Manole, Director, Promo-Lex

Igor Munteanu, Director, Institute for Development and Social Initiatives (IDIS-'Viitorul')

Sergiu Ostaf, expert, CREDO

Andrei Popov, Executive Director, Foreign Policy Association (APE)

Valeriu Prohnițchi, economic expert

Victor Ursu, Executive Director, Soros Foundation Moldova

Alexandru Canțîr, Director, Committee for the Freedom of the Press

Vitali Catană, expert, Institute for Public Policies (IPP)

Victor Chirilă, Programme Director, Foreign Policy Association (APE)

Antonița Fonari, Director, 'Young and Free'

Mircea Eşanu, Anti-corruption Alliance

Veaceslav Ioniță, expert, Institute for Development and Social Initiatives (IDIS-'Viitorul')

Vlad Gribincea, lawyer

Iurie Pintea, Programme Director, Institute for Public Policies (IPP)

Eugen Revenco, Programme Director, Foreign Policy Association (APE)

Alexei Tulbure, Director, 'Helsinki' Citizens Assembly 